\title{
Hubungan Efikasi Diri Pengambilan Keputusan Karier dan Pengambilan Keputusan Karier pada Siswa SMA
}

\author{
Adhi Darmasaputro, William Gunawan \\ Fakultas Psikologi UKRIDA Jakarta \\ email: william.gunawan@ukrida.ac.id
}

\begin{abstract}
Abstrak
Pengambilan keputusan karier adalah proses yang penting bagi siswa SMA, khususnya dalam menentukan masa depan karier mereka. Salah satu faktor yang dibutuhkan untuk memiliki pengambilan keputusan karier yang benar adalah efikasi diri pengambilan keputusan karier. Penelitian menunjukkan adanya perbedaan hasil korelasi antara kedua variabel. Penelitian ini bertujuan untuk mengetahui hubungan antara efikasi diri pengambilan keputusan karier dan pengambilan keputusan karier. Data dari 405 siswa SMA di Jakarta dianalisa dengan metode kuantitatif, menggunakan analisa korelasi Pearson dengan aplikasi SPSS 17. Pengumpulan data menggunakan kuesioner CDS (Career Decision Scale) dan CDSE-SF (Career Decision Self Efficacy Short Form) yang telah diterjemahkan ke dalam bahasa Indonesia. Uji validitas CDS menunjukkan hasil skor dari 0,334-0,641 sementara CDSE-SF menghasilkan skor 0,310-0,551. Hasil uji reliabilitas untuk skala CDS sebesar 0,866 dan 0.840 untuk skala CDSE-SF. Hasil penelitian ini menunjukkan tidak ada hubungan antara efikasi diri pengambilan keputusan karier dan pengambilan keputusan karier $(r=0,094, p>0,05)$. Penelitian ini memberikan kontribusi dalam bidang psikologi pendidikan khususnya dalam pengambilan keputusan karier remaja.
\end{abstract}

Kata kunci: efikasi diri pengambilan keputusan karier, pengambilan keputusan karier, remaja

\section{Relationship of Self Efficacy Career Decision Making and Decision Making Career for High School Students}

\begin{abstract}
Career decision making is an important process among highschool students, especially in determining their career future. One of the factor needed to have a clear decision making is career decision making self-efficacy. Different result found in the correlation between these two variables. This study aimed to determine the corellation of career decision-making self-efficacy and career decision making. Using 405 highschool students in Jakarta, quantitative analysis with Pearson product moment correlation was conducted using SPSS 17 application. Data collected using Using CDS (Career Decision Scale) and CDSE-SF (Career Decision Self Efficacy-Short Form) which has been translated into Indonesian. The reliability score from CDS and CDSE-SF was 0,866 and 0,840 . The CDS validity score was $0,334-0,641$ and CDSE-SF validity score was $0,310-0,551$. The results showed that there was no correlation between career decision making self-efficacy and career decision making $(r=0.094, p>0.05)$. This study has contributed in the field of educational psychology research especially in adolescent career decision making.
\end{abstract}

Keywords: career decision-making self-efficacy, career decision making, adolescent.

\section{Pendahuluan}

Permasalahan pengambilan keputusan karier merupakan masalah yang sering terjadi pada remaja yang baru saja usai menamatkan pendidikan SMA. Super (Brown
\& Lent, 2005; Callanan \& Greenhaus, 2006) mengatakan remaja pada usia 16-17 tahun (tingkat akhir SMA) sudah mulai merencenakan masa depan mereka. Remaja di usia ini juga secara kognitif meninjau diri mereka dan situasi hidupnya. Namun, mereka belum me- 
mutuskan pilihan bidang apa yang akan mereka jalani. Tahapan setelah peninjauan diri dan perencanaan ialah mereka harus mengarahkan diri pada bidang tertentu baik belajar formal (kuliah dan kursus) maupun melakukan kerja informal (magang, extension, dll). Pada tahap ini, mau tidak mau, mereka harus mengambil keputusan karier.

\section{Pengambilan Keputusan Karier}

Pengambilan keputusan karier merupakan suatu proses kompleks yang memerlukan pemrosesan informasi tentang diri sendiri dan karier di masa depan (Creed, Wang \& Hood, 2009). Menurut Parson, pengambilan keputusan karier merupakan proses dimana seseorang mengenali dirinya, mencari tahu tentang cakupan pekerjaan yang akan ia ambil, dan memiliki kemampuan untuk mengintegrasikan kedua hal tersebut dalam pilihan karir yang akan ia ambil (Creed et al., 2009). Sementara itu, Lee, Rojewski dan Hill (2013) mendefinisikan pengambilan keputusan karier sebagai suatu proses yang meliputi pilihan untuk memilih pendidikan dan pekerjaan yang diliputi oleh kesempatan yang dapat ia ambil, minat, tipe kepribadian, perasaan akan hambatan, dan identitas vokasional yang dimilikinya. Selanjutnya, Rowland (2004) mengatakan bahwa pengambilan keputusan karier ialah proses seseorang mengintegrasikan pengetahuan akan pekerjaan dan pengetahuan diri yang akan membawa sesorang pada pilihan pekerjaan yang diambil.

Berdasarkan definisi tentang pengambilan keputusan karier diatas, dapat disimpulkan jika pengambilan keputusan karier merupakan proses yang dilakukan oleh individu dalam memilih pendidikan dan pekerjaan yang diliputi oleh aspek personal (minat, tipe kepribadian, identitas vokasional, perasaan akan hambatan) dan aspek informasi terkait pilihan yang akan ia ambil.

Reardon, Lenz, dan Sampson (2009) mengatakan, pengambilan keputusan karier digolongkan kedalam tiga kategori berdasarkan tingkat kejelasannya, yakni (1) jelas, individu yang mampu mengintegrasikan pengetahuan tentang dirinya dan pengetahuan tentang pilihannya lalu menyusun per- encanaan karier yang memuaskan dirinya dan bermanfaat bagi lingkungan sosialnya); (2) sedikit jelas, individu yang tidak memiliki komitmen terhadap pilihan pekerjaan atau pendidikan; dan (3) tidak jelas, individu yang sering tidak mampu membuat keputusan karier dan merasa stress akibat pertimbangan yang tidak kunjung usai.

Corkin, Arbona, Coleman, dan Ramirez (2008) membagi pengambilan keputusan karier kedalam empat dimensi yakni (1) kelemahan struktur yang menggambarkan kurangnya pengalaman, rasa pecaya diri dan pemahaman dalam pengambilan keputusan karier; (2) hambatan eksternal yaitu kebutuhan akan dukungan lebih lanjut dan informasi dalam mengambil keputusan karier; (3) pendekatan masalah dalam memilih pilihan karier yang menarik dan memungkinkan untuk diambil; dan (4) konflik personal, refleksi dari kesulitan dalam pengambilan keputusan karier seperti keinginan untuk mengejar karier yang diharapkan oleh orang lain yang dianggap penting.

\section{Efikasi Diri Pengambilan Keputusan Karier}

Dalam menyelesaikan tugas yang dibutuhkan dalam pengambilan keputusan karier, seseorang membutuhkan efikasi diri pengambilan keputusan karier (Betz \& Taylor, 2012; Chung, 2002). Efikasi Diri Pengambilan Keputusan Karier ialah penilaian individu mengenai kemampuannya untuk menyelesaikan tugas yang dibutuhkan dalam pengambilan keputusan karier (Betz \& Taylor, 2012; Kelly, 2010; Wolfe \& Betz, 2004). Flores, Scott, Yu-Wei, dan Yakushko (2006) mendefinisikan efikasi diri pengambilan keputusan karier sebagai suatu keyakinan pribadi bahwa seseorang mampu untuk menyelesaikan serangkaian tugas spesifik yang berkaitan dengan membuat suatu pengambilan keputusan karier. Kim et al.(2014) mendefinisikan efikasi diri pengambilan keputusan karier sebagai kepercayaan diri seseorang terhadap kemampuannya dalam meraih tujuan yang spesifik, menguasasi situasi dan menghasilkan keputusan karier yang tepat.

Berdasarkan uraian diatas, dapat disimpulkan bahwa efikasi diri pengambilan 
keputusan karier ialah keyakinan, kepercayaan diri dan penilaian individu terhadap kemampuannya dalam melakukan serangkaian tugas yang berkaitan dengan pengambilan keputusan karier.

Betz dan Taylor (2012) mengatakan, efikasi diri pengambilan keputusan karier terdiri dari beberapa komponen yakni penilaian diri (kemampuan individu untuk menilai tujuan, keahlian , dan minat individu tersebut), informasi pekerjaan (informasi yang berisi penjelasan pekerjaan tertentu), pemilihan tujuan (kemampuan seseorang untuk menentukan tujuan karir berdasarkan penilaian diri yang dilakukannya), perencanaan (kemampuan individu untuk merencanakan persiapan kerja dan tugas-tugas yang menyertai persiapan tersebut), dan penyelesaian masalah (kemampuan individu untuk menghadapi kesulitan-kesulitan yang terkait dengan karier ).

Kim et al. (2014) dalam penelitiannya menyatakan, kejelasan pengambilan keputusan karier remaja tidak terlepas dari peran efikasi diri remaja dalam pengambilan keputusan karier. Semakin remaja memiliki efikasi diri yang tinggi, semakin jelas keputusan karier yang diambil. Bandura mengatakan salah satu faktor yang terdapat dalam proses pengambilan keputusan karier ialah efikasi diri (Brown \& Lent, 2005). Efikasi diri memegang peran penting karena akan menentukan kejelasan keputusan karier yang dibuat.

Penelitian sebelumnya yang dilakukan oleh Peilouw dan Nursalim (2013) menghasilkan temuan jika terdapat hubungan yang positif dan signifikan antara efikasi diri dengan kemampuan pengambilan keputusan karier pada remaja. Namun, penelitian yang dilakukan oleh Creed, Patton, dan Bartrum (2004) mengatakan, apabila remaja memiliki persepsi tentang hambatan karier (internal dan eksternal) atau kondisi kehidupannya menghambat remaja untuk mengambil keputusan karier (kemiskinan, keterbatasan informasi, tingkat intelektual rendah), efikasi diri tidak lagi memiliki hubungan terhadap pengambilan keputusan karier. Dari kedua hasil penelitian yang berbeda, maka perlu diteliti apakah terdapat hubungan antara efikasi diri pengambilan keputusan karier dan pengambilan keputusan karier pada siswasiswi SMA?

\section{Metode}

\section{Subjek}

Subjek dalam penelitian ini siswasiswi kelas XII SMA di kecamatan Grogol Petamburan. Pengambilan data dimulai bertempat di beberapa SMA di kecamatan Grogol Petamburan. Proses pengambilan sampel menggunakan teknik sampling purposive. Pengambilan menggunakan sampling purposive dikarenakan pertimbangan teretentu yakni keterbatasan waktu yang dimiliki oleh peneliti dan rencana intervensi karier dari Universitas peneliti di kecamatan Grogol Petamburan. Dari proses sampling yang dilakukan, diperoleh 405 subjek yang terbagi dalam tujuh sekolah.

\section{Pengukuran}

Pengambilan data dilakukan dengan meminta subjek untuk mengisi dua buah kuesioner yaitu Career Decision Scale (CDS, Osipow, 1994) dan Career Decision Self-Eficacy Scale (CDSE, Taylor \& Betz, 2012) yang telah diterjemahkan ke dalam Bahasa Indonesia dan mengalamai proses back translation ke dalam Bahasa Inggris.

Pengambilan keputusan karier diukur menggunakan merupakan skor total dari alat ukur CDS (career decision scale) yang merupakan skala Likert dengan pilihan mulai dari 1 (sangat sesuai) sampai 5 (sangat tidak sesuai). Adapun dalam skor tersebut mencakup aspek kelemahan struktur, hambatan eksternal, pendekatan masalah, dan konflik personal subjek dalam pengambilan keputusan karier. Selanjutnya, menurut Hartman et al. (Creed, Patton, \& Prideaux, 2006) validitas untuk skala CDS dilakukan dengan menggunakan 3 metode yakni concurrent validity, construct validity dan predictive validity. Skor yang dihasilkan dari construct validity sebesar 0, 61-0,90. Creed et al. (2006) dalam penelitiannya mengatakan jika reliabilitas alat tes CDS telah dilakukan. Reliabilitas dilakukan dengan metode konsistensi internal. Skor yang dihasilkan sebesar 0,80 . Skor tersebut 
menunjukkan bahwa alat ukur ini memiliki validitas dan realibilitas yang baik (Azwar, 2012; Sarwono, 2012).

Efikasi diri pengambilan keputusan karier diukur menggunakan skor total dari alat ukur CDSE-SF (career decision self efficacy short form) yang merupakan skala Likert dengan pilihan 1 (sangat tidak sesuai) sampai 5 (sangat sesuai). Dari skor tersebut akan bisa diketahui tinggi rendahnya skor keyakinan diri subjek dalam melakukan tugas karier yang berkaitan dengan pengambilan keputusan. Adapun dalam skor tersebut mencakup aspek penilaian diri, pencarian informasi, penentuan tujuan, perencanaan, dan pemecahan masalah.

Reliabilitas untuk alat tes CDSE telah dilakukan. Menurut Betz dan Taylor (2012) uji konsistensi internal menghasilkan reliabilitas sebesar 0,93; sedangkan untuk testretest menghasilkan skor reliabilitas sebesar 0,83 . Alat test ini juga sudah diadaptasi dalam konteks Indonesia. Menurut Gunawan (2013) skor reliabilitas untuk alat tes yang sudah dalam konteks Indonesia sebesar 0,893. Metode yang digunakan dalam uji reliabilitas yakni konsistensi internal dengan rumus alpha cronbach. Gunawan (2013) menjelaskan alat ini juga diuji validitas dalam konteks Indonesia dan diperoleh skor berkisar 0,240 sampai 0,790 . Terdapat satu aitem yang ditolak.

\section{Hasil Uji Validitas dan Reliabilitas Alat Ukur} Pelaksanaan uji validitas dan reliabilitas alat ukur dilakukan di sekolah peneliti melakukan magang, yakni SMA XXX, kota Tangerang. Sebanyak 221 siswa-siswi kelas XII baik dari jurusan IPA maupun IPS menjadi sampel. Pemilihan subjek di sekolah ini didasarkan karena fenomena yang diperoleh peneliti berasal dari sekolah ini.

Uji reliabilitas pada alat ukur pengambilan keputusan karier dilakukan dengan metode konsistensi internal dan uji validitas skala ini juga dihitung menggunakan validitas konstruk (korelasi aitem total). Hasil uji reliabilitas pada skala pengambilan keputusan karier sebesar 0,866 . Selanjutnya pada validitas alat ukur terdapat satu aitem (nomor 18) yang ditolak karena memiliki angka dibawah 0,3 (Sarwono, 2009). Oleh karena hal tersebut, hanya digunakan 15 aitem dalam skala pengambilan keputusan karier. Adapun rentang validitas 15 aitem tersebut dari 0,334 sampai dengan 0,641.

Uji validitas skala efikasi diri pengambilan keputusan karier dihitung menggunakan validitas konstruk (korelasi aitem total) dengan rumus Alpha Cronbach. Terdapat enam item $(01,13,16,17,18,25)$ ditolak pada skala efikasi diri pengambilan keputusan karier. Hal ini dikarenakan, keenam aitem tersebut memiliki angka perhitungan dibawah 0,3 . Berdasarkan hal tersebut, terdapat 19 aitem yang digunakan pada skala efikasi diri pengambilan keputusan karier. Adapun rentang koefisien validitas 19 aitem tersebut dari 0,310 sampai dengan 0,551 . Selanjutnya, uji reliabilitas skala efikasi diri pengambilan keputusan karier dilakukan dengan pendekatan konsistensi internal (internal consistency). Hasil reliabilitas skala efikasi diri pengambilan keputusan karier sebsesar 0,840.

\section{Hasil}

Uji Asumsi

Sebelum dilakukan proses analisa lebih lanjut, skala yang telah dipisahkan dari aitem-aitem yang tidak valid terlebih dahulu dilakukan uji asumsi. Hal tersebut dilakukan untuk mengetahui normal atau tidaknya sebaran aitem.

\section{Uji Normalitas}

Uji normalitas data dengan menggunakan metode Kolmogorov-Smirnov Goodnes of Fit. Hasil uji normalitas pada variabel efikasi diri pengambilan keputusan karier menunjukkan nilai KolmogorovSmirnov Goodness of Fit sebesar 0,095 dengan $p>0,05$, sedangkan uji normalitas pada variabel pengambilan keputusan karier menunjukkan nilai sebesar 0,349 dengan $p>0,05$. Karena signifikansi yang diperoleh lebih besar dari 0,05 maka data yang diperoleh berdistribusi normal (Azwar, 2013; Sarwono, 2012). 


\section{Uji Linearitas}

Pengujian lineraitas dilakukan untuk membuktikan asusmsi hubungan garis lurus antara variabel penelitian. Menurut Sarwono (2012), linearitas dapat diartikan sebagai asumsi adanya hubungan dalam bentuk garis lurus antar dua variabel. Adapun penilaiannya dapat melalui observasi dari scatterplots bivariat. Adapun hasil scatterplots variabel penelitian ini sebagai berikut :

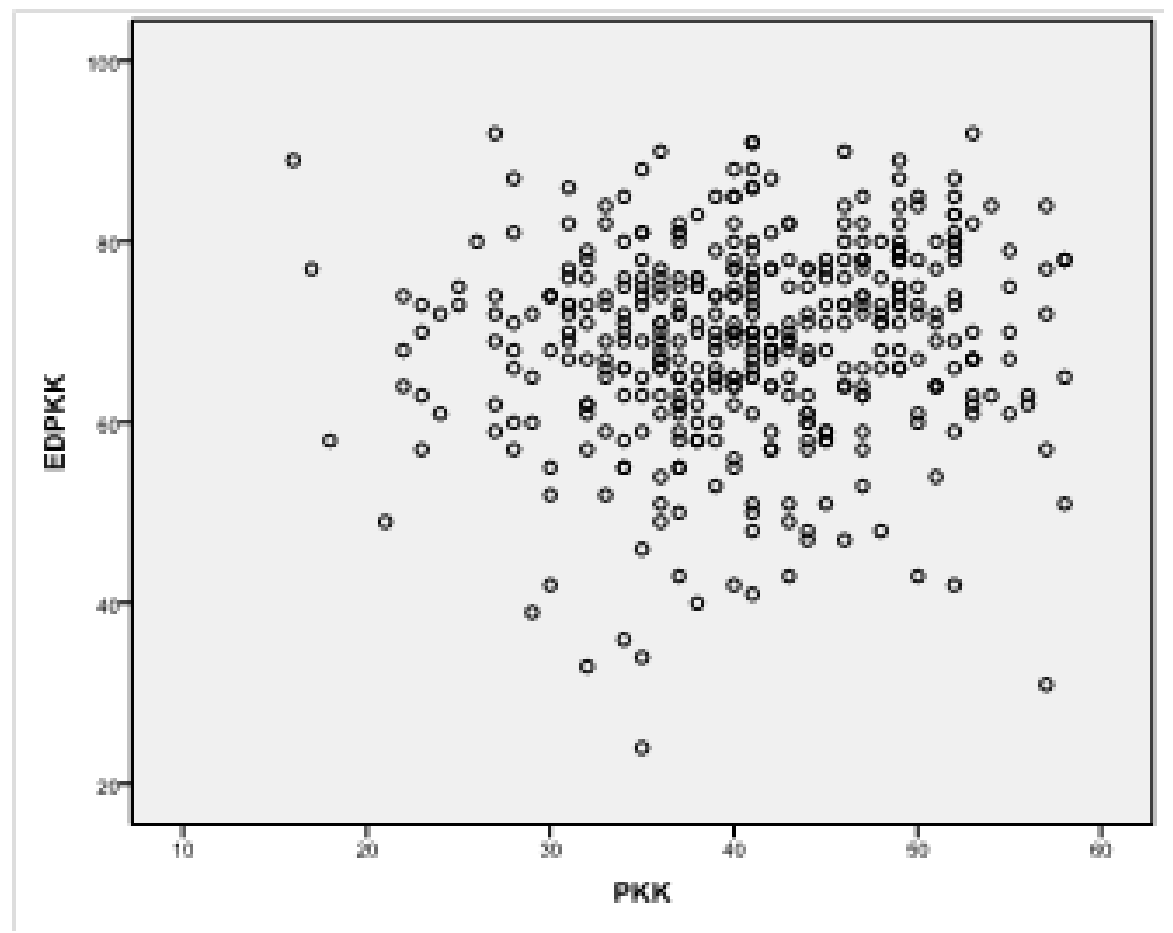

Gambar 1. Uji linearitas

Berdasarkan hasil observasi scatterplot yang dilakukan dapat disimpulkan jika data yang diperoleh tidak linier. Hal ini dikarenakan scatterplot tidak berbentuk oval dalam satu garis lurus.

Pengambilan Keputusan Karier di Kecamatan Grogol Petamburan

Dalam penelitian ini, diperoleh mean pengambilan keputusan karier sebesar 41,08 dengan jumlah subjek sebanyak 405 siswa. Sebanyak $9 \%$ subjek berada dalam kategori tidak jelas, $60 \%$ subjek berada dalam kategori cukup jelas, dan $31 \%$ berada dalam kategori jelas. Berdasarkan data tersebut, ratarata siswa-siswi kelas XII SMA di Kecamatan Grogol Petamburan memiliki pengambilan keputusan kariernya berada dalam kategori cukup jelas. Hal ini dapat dilihat dari kesu- litan mereka dalam memilih jurusan karena jurusannya bertentangan dengan orang tua, merasa mustahil untuk meraih jurusan yang diinginkan, dan tidak dapat membuat keputusan karier sekarang karena tidak mengetahui kemampuan yang dimilikinya. Skor minimal yang diperoleh sebesar 15 dan skor maksimal sebesar 60 .

Kategorisasi Berdasarkan Dimensi Pengambilan Keputusan Karier

Untuk melihat lebih lanjut tentang bagaimana kondisi pengambilan keputusan karier subjek berdasarkan dimensi dari pengambilan keputusan karier, peneliti mengunakan mean empiric dalam menggolongkan tinggi rendahnya skor masing masing dimensi. Adapun hasilnya sebagai berikut 


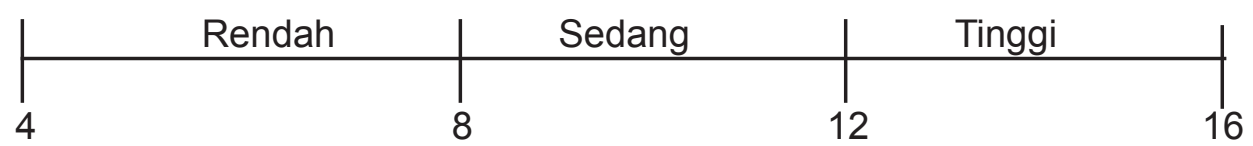

Tabel 1. Kategorisasi Pengambilan Keputusan Karier

\begin{tabular}{lll}
\hline Dimensi & Kategori & Mean \\
\hline Kelemahan Struktur & Tinggi & 13,82 \\
Hambatan Eksternal & Rendah & 7,17 \\
Pendekatan Masalah & Tinggi & 16,71 \\
Konflik Personal & Rendah & 3,02 \\
\hline
\end{tabular}

Efikasi Diri Pengambilan Keputusan Karier Dalam penelitian ini, diperoleh mean efikasi diri pengambilan keputusan karier sebesar 68,95 dengan jumlah subjek sebanyak 405 siswa. Sebanyak 1\% subjek memiliki efikasi diri pengambilan keputusan karier yang rendah sekali, $11 \%$ rendah, $62 \%$ tinggi, dan $25 \%$ tinggi sekali. Berdasarkan data tersebut, rata-rata siswa-siswi kelas XII SMA di Kecamatan Grogol Petamburan memiliki efikasi diri pengambilan keputusan karier yang tinggi. Hal ini dapat dilihat dari keyakinan mereka dalam memilih satu diantara beberapa beberapa pilihan jurusan yang diminati, menilai kemampuan mereka secara akurat, menentukan pekerjaan yang ideal, mengenali institusi yang relevan dengan pilihan jurusan mereka, dan menemukan gaya hidup yang akan mereka jalani. Skor minimal yang diperoleh sebesar 24 dan skor maksimal sebesar 92.

Kategorisasi Berdasarkan Aspek-Aspek Efikasi Diri Pengambilan Keputusan Karier

Selanjutnya, peneliti akan menggunakan kategorisasi untuk membedakan siswasiswi berdasarkan lima aspek yang terdapat dalam efikasi diri pengambilan keputusan karier. Untuk menentukan tinggi rendahnya hasil pengukuran lima aspek dalam efikasi diri pengambilan keputusan karier, peneliti menggunakan empat kategori yaitu rendah sekali, rendah, tinggi, dan tinggi sekali. Penggolongan kategori tersebut dilakukan peneliti berdasarkan mean empirik yang diperoleh.

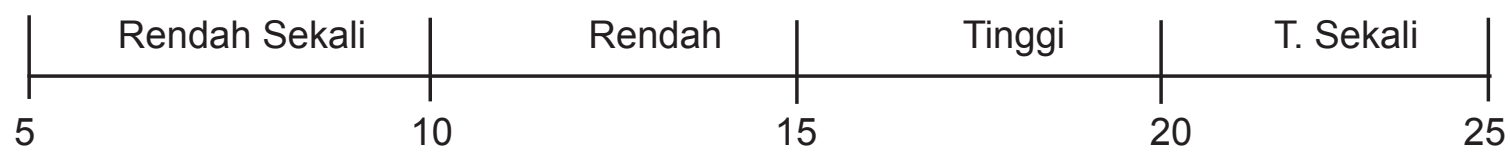

Tabel 2. Kategorisasi Efikasi Diri Pengambilan Keputusan Karier

\begin{tabular}{lll}
\hline Dimensi & Kategori & Mean \\
\hline Penilaian Diri & Tinggi & 18.55 \\
Pencarian Informasi & Rendah & 13.47 \\
Penentuan Tujuan & Tinggi & 15.55 \\
Perencanaan & Tinggi & 17.68 \\
Pemecahan Masalah & Rendah Sekali & 3.60 \\
\hline
\end{tabular}

Uji Hipotesis

Hasil uji korelasi antara efikasi diri pengambilan keputusan karier dengan pengambilan keputusan karier pada siswasiswi kelas XII SMA di kecamatan Grogol
Petamburan menunjukkan nilai $r=0,094$ dengan $p>0,05$. Hal tersebut memiliki arti bahwa tidak terdapat hubungan yang signifikan antara efikasi diri pengambilan keputusan karier dengan pengambilan keputusan karier 
pada siswa-siswi kelas XII SMA di kecamatan Grogol Petamburan.

Perbedan Karakteristik Berdasarkan Data Demografis

Berdasarkan data demografis yang diperoleh, peneliti ingin melihat apakah terdapat perbedaan pada masing-masing karaketristik. Adapun karaketristik yang dimaksud ialah kelas (XII IPA \&XII IPS), Usia (16-20 thn), jenis kelamin (laki-laki dan perempuan), asal sekolah (sekolah subjek penelitian). Proses penghitungan dilakukan mengggunakan Uji Beda rata-rata -Uji Varian satu arah (One way Anova). Hasil penghitungannya terangkum dalam tabel 3 dan 4.

Hasil perhitungan memperlihatkan tidak ada perbedaan dalam pengambilan keputusan karier berdasarkan kelas, usia, jenis kelamin dan asal sekolah.

Tabel 3. Pengambilan Keputusan Karier

\begin{tabular}{lllll}
\hline & Kelas & Usia & Jenis Kelamin & Asal Sekolah \\
\hline \multirow{2}{*}{ Hasil Uji Beda } & 0,$562 ; p>0,05$ & 1,$350 ; p>0,05$ & 1,$018 ; p>0,05$ & 1,$684 ; p>0,05$ \\
& $(0,251)$ & $(0,454)$ & $(0,314)$ & $(0,123)$ \\
\multirow{2}{*}{ Kesimpulan } & Tidak Ada & Tidak Ada & Tidak Ada & Tidak Ada \\
& Perbedaan & Perbedaan & Perbedaan & Perbedaan \\
\hline
\end{tabular}

Hasil perhitungan menunjukkan adanasal sekolah, namun tidak ada perbedaan ya perbedaan signifikan dalam efikasi diri berdasarkan kelas, usia dan jenis kelamin. pengambilan keputusan karier berdasarkan

Tabel 4. Hasil Efikasi Diri Pengambilan Keputusan Karier

\begin{tabular}{lllll}
\hline & Kelas & Usia & Jenis Kelamin & Asal Sekolah \\
\hline Hasil Uji Beda & 0,$525 ; p>0,05$ & 1,$715 ; p>0,05$ & 6,$080 ; p>0,05$ & 4,$576 ; p<0,05$ \\
& $(0,469)$ & $(0,146)$ & $(0,14)$ & $(0,00)$ \\
Kesimpulan & Tidak Ada & Tidak Ada & Tidak Ada & Ada Perbedaan \\
& Perbedaan & Perbedaan & Perbedaan & \\
\hline
\end{tabular}

\section{Pembahasan}

Uji hipotesis tentang hubungan antara efikasi diri pengambilan keputusan karier dengan pengambilan keputusan karier menemukan bahwa tidak terdapat hubungan yang signifikan antara efikasi diri pengambilan keputusan karier dengan pengambilan keputusan karier. Hal tersebut juga didukung oleh penelitian sebelumnya. Penelitian yang dilakukan oleh Creed et al. (2006) menghasilkan temuan bahwa perubahan efikasi diri pengambilan keputusan karier, tidak serta merta diikuti perubahan pengambilan keputusan karier. Hasil penelitian ini kontras dengan hipotesis yang dibuat oleh Creed et al. (2006) yang menyatakan terdapat hubungan yang kuat dan signifikan antara efikasi diri pengam- bilan keputusan karier dengan pengambilan keputusan karier.

Menurut peneliti, tidak adanya hubungan antara efikasi diri pengambilan keputusan karier dan pengambilan keputusan karier disebabkan oleh adanya situasi yang ganjil pada subjek. Berdasarkan hasil yang dihimpun rata-rata subjek memiliki efikasi diri pengambilan keputusan karier yang tinggi, namun memiliki status pengambilan keputusan karier yang sedikit jelas. Apabiila ditinjau secara spesifik berdasarkan kategorisasi atau aspek -aspeknya subjek memiliki skor tinggi pada aspek penilain diri, penentuan tujuan dan perencanaan. Namun hal tersebut juga diikuti tingginya aspek kelemahan struktur (menggambarkan kurangnya pengalaman, rasa pecaya diri dan pemahaman dalam 
mengambilan keputusan karier) dan pendekatan masalah (masalah dalam memilih pilihan karier yang menarik dan memungkinkan untuk diambil).

Adapun dalam penelitian ini, efikasi diri pengambilan keputusan karier yang dihasilkan berada dalam kategori tinggi. Hasil penghitungan yang dilakukan, diperoleh rata-rata skor subjek pada skala efikasi diri pengambilan keputusan karier sebesar 68,95. Menurut Susantoputri \& Gunawan (2014), seseorang yang memiliki efikasi diri yang tinggi akan merasa mampu untuk melaksanakan tugas perkembangan karier yang dihadapinya. Mereka akan berusaha keras untuk menghadapi kesulitan yang berkaitan dengan karier yang mereka pilih, contohnya seperti pilihan alternatif pekerjaan. Hal tersebut didukung oleh Bandura (1977) yang menyatakan bahwa seseorang yang memiliki efikasi diri yang tinggi, akan mengeluarkan usaha yang besar untuk mengatasi hambatan dalam mencapai tujuannya.

Hasil efikasi diri pengambilan keputusan karier yang tinggi, konsisten dengan nilai rata-rata masing-masing dimensi yang dihasilkan berdasarkan perhitungan yang dilakukan. Nilai rata-rata dimensi penilaian diri 18,55; dimensi pencarian informasi 13,47; dimensi penetuan tujuan 15,55 ; dimensi perencanaan 17,68; dan pemecahan masalah sebesar 3,60 . Dengan demikian dapat diasumsikan jika seseorang yang memilki efikasi diri yang tinggi ditandai dengan adanya penilaian diri yang baik, pencarian informasi yang akurat, kejelasan dalam penentuan tujuan, dan perencanaan yang baik. akan menjadi tinggi sekali dalam efikasi diri pengambilan keputusan karier jika memiliki kemampuan dalam memecahkan masalah yang baik.

Dalam penelitian ini, ditemukan tidak terdapat perbedaan efikasi diri pengambilan keputusan karier berdasarkan kelas. Hasil penghitungan tersebut didukung oleh penelitian yang dilakukan Rowland (2004) yang menghasilkan temuan tidak terdapat perbedaan efikasi diri pengambilan keputusan karier dalam kelas yang berada dalam satu jenjang. Perbedaan ditemukan jika kelas tersebut berbeda jenjang.
Selanjutnya, ditemukan tidak adanya perbedaan efikasi diri pengambilan keputusan karier berdasarkan usia Hal tersebut juga didukung oleh penelitian Gunawan (2013). Menurut Gunawan (2013), tidak ditemukan adanya perbedaan skor efikasi diri pengambilan keputusan karier berdasarkan usia.

Feist dan Feist (2008) menyatakan bahwa efikasi diri bervariasi dari satu situasi ke situasi lainnya, tergantung dari kompetensi yang dibutuhkan pada aktivitas yang berbeda, ada atau tidak adanya orang lain, kompetensi yang dirasakan oleh orang-orang lain, kecenderungan untuk menghadapi kegagalan daripada keberhasilan serta keadaan fisiologis yang menyertai. Sejalan dengan pernyataan tersebut, dalam penelitian ini ditemukan terdapat perbedaan efikasi diri pengambilan keputusan karier berdasarkan asal sekolah.

Menurut Super (Ginantonio \& Hurley-Hanson, 2006), seseorang yang berada dalam usia 16-24 tahun berada dalam tahap eksplorasi. Pada tahapan ini, seseorang sudah memikirkan alternative jabatan, namun belum mengambil keputusan yang tepat. Hal ini diperkuat oleh hasil penelitian yang menyatakan bahwa status pengambilan keputusan karier siswa-siswi kelas XII SMA di kecamatan Grogol Petamburan sedikit jelas dan tidak adanya perbedaan pengambilan keputusan karier berdasarkan usia.

Kemudian, dalam penelitian ini ditemukan pula tidak adanya perbedaan pengambilan keputusan karier berdasarkan jenis kelamin. Hal tersebut serupa dengan temuan Okubo, Yeh, Lin, Fujita \& Shea (2007) yang menunjukkan tidak ada perbedaan pengambilan keputusan karier baik pada pria maupun wanita pada remaja Amerika yang berdomisili di jepang.

Hijazi, Tatar, \& Gati (2004) menyatakan bahwa tidak ada perbedaan pengambilan keputusan karier pada lokasi sekolah yang berada di wilayah SMA di Israel. Hal tersebut serupa dengan temuan peneliti dalam penelitian ini. Berdasarkan hasil penghitungan yang dilakukan, tidak terdapat perbedaan pengambilan keputusan karier berdasarkan asal sekolah. 
Dalam penelitian ini belum dibahas kaitan antara status sosial ekonomi dengan efikasi diri pengambilan keputusan karier maupun pengambilan keputusan karier. Menurut Creed (dalam Waters, 2010), pengambilan keputusan karier dipengaruhi oleh faktor internal dan eksternal. Faktor internal meliputi informasi tentang individu itu sendiri seperti minat, bakat, kemampuan, tipe kepribadian. Adapun faktor eksternal meliputi informasi tentang pilihan karier yang akan diambil, lingkungan keluarga, status ekonomi sosial, dan budaya. Demikian pula untuk variabel-variabel lain yang belum dibahas seperti career barier, locus of control dan dukungan sosial. Variabel-variabel tersebut juga belum dapat dibahas dalam penelitian ini.

\section{Kesimpulan}

Berdasarkan hasil yang didapatkan dan telah dibahas, dapat disimpulkan bahwa hipotesis yang peneliti ajukan ditolak, yaitu tidak terdapat hubungan yang signifikan antara efikasi diri pengambilan keputusan karier dengan pengambilan keputusan karier pada siswa-siswi kelas XII SMA di Kecamatan Grogol Petamburan.

\section{Daftar Pustaka}

Azwar, S. (2012). Penyusunan Skala Psikologi (Edisi 2). Yogyakarta : Pustaka Pelajar.

Azwar, S. (2013). Metode Penelitian. Yogyakarta : Pustaka Pelajar.

Bandura, A. (1977). Social Learning Theory. New Jersey : Prentice Hall, Inc.

Betz, N.E. \& Taylor, K.M. (2012). Career Decision Self Efficacy Scale and Short Form Sampler set : Manual, Instrument, and Scoring Sheet. www.mindgarden.com.

Bloxom, J. M., Bernes, K. B., Magnusson, K. C., Gunn, T. T., Bardick, A. D., Orr, D. T., \& McKnight, K. M. (2008). Grade 12 student career needs and perceptions of the effectiveness of career development services within high schools. Canadian
Journal of Counselling, 42(2), 79-100. Diunduh dari http://search.proquest. com/docview/195793487? account id $=50673$

Brown, S.D. \& Lent, R.W. (2005) Preparing Adolescents to Make Career Decision. Conecticut : Information Age Publishing.

Chung, Y. B. (2002). Career decisionmaking self-efficacy and career commitment: Gender and ethnic differences among college students. Journal of Career Development, 28(4), 277. Diunduh dari http://search.proquest.com/ docview $/ 220426020$ ? accountid= 50673

Corkin, D., Arbona, C., Coleman, N., \& Ramirez, R. (2008). Dimensions of career indecision among puerto rican college students. Journal of College Student Development, 49(2), 81-94. Diunduh dari http://search. proquest.com/docview/195185654? accountid $=50673$

Creed, P. A., Patton, W., \& Bartrum, D. (2004). Internal and external barriers, cognitive style, and the career development variables of focus and indecision. Journal of Career Development, 30(4), 277-294. Diunduh dari http://search.proquest. com/docview/220393683?accountid= 50673

Creed, P. \& Patton, W. \& Prideaux, L.A. (2006). Causal Relationship Between Career Indecision and Career Decision-Making Self-Efficacy: A Longitudinal Cross-Lagged Analysis. Journal Of Career Development 33 (1):pp. 47-65.

Creed, P. A., Wong, O. Y., \& Hood, M. (2009). Career decision-making, career barriers and occupational aspirations in chinese adolescents. International Journal for Educational and Vocational Guidance, 9(3), 189-203. doi:http://dx.doi.org/10.1007/s10775009-9165-0

Feist, J., \& Feist, G.J. (2008). Teori Kepribadi- 
an : Theories of Personality (Edisi,7). Jakarta : Salemba Humanika.

Flores, L. Y., Scott, A. B., Yu-Wei, W., Yakushko, O., \& al, e. (2006). Practice and research in career counseling and development-2002. The Career Development Quarterly, 52(2), 98-131. Diunduh dari http:// search.proquest.com/docview/ 219543964 ? accountid $=50673$

Giannantonio, C. M., \& Hurley-Hanson, A. (2006). Applying image norms across super's career development stages. The Career Development Quarterly, 54(4), 318-330. Diunduh dari http:// search.proquest.com/docview/21938 9774 ? accountid $=50673$.

Gunawan, W. (2013). Pengaruh SumberSumber Efikasi Diri dan Efikasi Diri Pengambilan keputusan Karier terhadap Adaptabilitas Karier Remaja (Tesis Tidak Diterbitkan). Universitas Indonesia, Depok.

Hijazi, Y., Tatar, M., \& Gati, I. (2004). Career decision-making difficulties among israeli and palestinian arab highschool seniors. Professional School Counseling, 8(1), 64-72. Diunduh dari http://search.proquest.com/docview/ 213442759 ? accountid $=50673$

Kelly, R. R. (2010). The relationship between career decision-making self-efficacy and perceived career barriers in the career decision making of selected community college students. Disertation. Missipi : University of Missipi.

Kim, B., Jang, S. H., Jung, S. H., Lee, B. H., Puig, A., \& Lee, S. M. (2014). A moderated mediation model of planned happenstance skills, career engagement, career decision selfefficacy, and career decision certainty. The Career Development Quarterly, 62(1), 56-69. Diunduh dari http://search.proquest.com/ docview/1555300832 ? accountid = 25704

Lee, I. H., Rojewski, J. W., \& Hill, R. B. (2013). Classifying korean adoles- cents' career preparedness. International Journal for Educational and Vocational Guidance, 13(1), 25-45. doi:http://dx.doi.org/10.1007/ s10775-012-9236-5

Okubo, Y., Yeh, C. J., Lin, P., Fujita, K., \& Shea, J. M. (2007). The career decision-making process of chinese american youth. Journal of Counseling and Development: JCD, 85(4), 440-449. Diunduh dari http:// search.proquest.com/docview/ 218970641 ? accountid=50673.

Osipow, S.H. (1994). The career decision scale: How good does it have to be? Journal of Career Assessment, 2, 1, 15-18. Doi: 10.1177/106907279400 200102

Peilouw, F.J. \& Nursalim, M. (2013). Hubungan antara pengambilan keputusan dengan kematangan informasi dan self-efficacy pada remaja. Character, 01(02), 1-5.

Reardon, R.C. , Lenz, J.G. \& Sampson, J.P. (2009). Career Development and Planning, A comprehensive Approach. Ohio : Cengage Learning.

Rowland, K. D. (2004). Career decisionmaking skills of high school students in the Bahamas. Journal of Career Development, 31(1), 1-13. Diunduh dari http://search.proquest.com/doc view $/ 220425034$ ? accountid $=50673$

Sarwono, J. (2012). Prosedur-Prosedur Populer Statistik untuk Mempermudah Riset Skripsi. Metamorfosis, 6(22), 104-121.

Sarwono, J. (2012). Metode Riset Skripsi Pendekatan Kuantitatif : Menggunakan Prosedur SPSS : Tuntunan Praktis dalam Menyusun Skripsi. Jakarta : Elex Media Komputindo.

Sarwono, S. (2009). Psikologi Sosial. Jakarta : Salemba Humanika.

Super's Career Development Theory. (2006). In G. A. Callanan \& J. H. Greenhaus (Eds.), Encyclopedia of Career Development (Vol. 2, pp. 789-792). Thousand Oaks, CA: SAGE Reference. Diunduh dari http:// 
go.galegroup.com/ps/i.do?id= GALE\%7CCX3469900288\&v=2.1\&u= idpnri\&it $=r \& p=G V R L \& s w=w \&$ asi $d=7 a 1 f 71947 f 648 b d f 247 c 35 e b f$ $67 a 6 c f 6$

Susantoputri, M.K. \& Gunawan, W. (2014).
Hubungan antara efikasi diri karier dengan kematangan karier pada remaja di daerah kota Tangerang. Jurnal Psikologi UIN Suska, 10 (1), 59-65.

Watters, J. J. (2010). Career decision making among gifted students: The mediation of teachers. The Gifted Child Quarterly, 54(3), 222-238. Diunduh dari http://search.proquest. com/docview/608815460?account $\mathrm{id}=50673$

Wolfe, J. B., \& Betz, N. E. (2004). The relationship of attachment variables to career decision-making selfefficacy and fear of commitment. The Career Development Quarterly, 52(4), 363-369. Diunduh dari http:// search.proquest.com/docview/21944 5099? accountid=50673 